J. Pijar MIPA, Vol. VI No.1, Maret : 5 - 8

ISSN 1907-1744

\title{
PEMBELAJARAN KOOPERATIF BERKIRIM SALAM DAN SOAL UNTUK MENINGKATKAN AKTIVITAS DAN HASIL BELAJAR MAHASISWA PENDIDIKAN MATEMATIKA FKIP UNRAM PADA MATA KULIAH KIMIA DASAR
}

\author{
Yunita Arian Sani Anwar, Mukhtar Haris \\ Program Studi Pendidikan Kimia, Jurusan PMIPA FKIP Universitas Mataram \\ Jl. Majapahit 62 Mataram, 83125 \\ Email: rian_bik@yahoo.com
}

\begin{abstract}
Abstrak : Penelitian ini bertujuan untuk meningkatkan aktivitas dan hasil belajar mahasiswa semester 2 Program Studi Pendidikan Matematika FKIP Unram tahun akademik 2008/2009 pada mata kuliah kimia dasar dengan menggunakan pembelajaran kooperatif berkirim salam dan soal. Penelitian ini dilaksanakan dalam 2 siklus. Kriteria keberhasilan penelitian adalah aktivitas mahasiswa aktif dan sangat sedikit mahasiswa yang mengalami kesalahan konsep. Hasil penelitian menunjukkan pembelajaran kooperatif berkirim salam dan soal dapat meningkatkan aktivitas dan hasil belajar mahasiswa. Pada siklus I sebanyak 52,10\% mahasiswa mengalami kesalahan konsep dan setelah siklus II menurun menjadi 18,15\%. Aktivitas mahasiswa pada siklus I pada kategori kurang aktif dan setelah siklus II meningkat menjadi aktif.

Kata kunci : Pembelajaran kooperatif, aktivitas, hasil belajar.

\section{COOPERATIVE LEARNING EXCHANGING GREETINGS AND QUESTIONS TO IMPROVEACTIVITY AND ACADEMIC ACHIEVEMENT OF STUDENTS OFMATHEMATICS EDUCATION PROGRAME FKIP UNIVERSITY OF MATARAM IN GENERAL CHEMISTRY SUBJECT}

\begin{abstract}
The research has been done to improve activity and academic achievement of second semester students of mathematics education program FKIP University of Mataram academic year 2008/2009 in general chemistry subject through cooperative learning exchanging greetings and questions. There were two cycles of learning in the research. The criteria of the success of the research are student activities were active and misconception student on low level. The results indicated that cooperative learning berkirim salam dan soal can improve activity and academic achievement students. In the first cycle was $52,10 \%$ students has misconception and in the second cycle has $18,15 \%$. Criteria students activity in first cycle was very low and in the second cycle students activity was active.

Key words : Cooperative learning, activity, academic achievement.
\end{abstract}

\section{PENDAHULUAN}

Ilmu kimia adalah ilmu yang mempelajari tentang susunan, struktur, sifat dan perubahan materi, serta energi yang menyertai perubahan materi tersebut. Pada tingkatan Perguruan Tinggi, khususnya pada Jurusan Pendidikan Matematika dan Ilmu Pengetahuan Alam (MIPA) Fakultas Keguruan dan Ilmu Pendidikan (FKIP), ilmu kimia dipelajari pada tahun pertama kuliah secara bersama di semester I dan atau semester II dengan nama mata kuliah Kimia Dasar atau Kimia.

Hasil belajar mata kuliah General Chemistry selama ini masih rendah akibat rendahnya tingkat penguasaan konsep kimia. Para peneliti di bidang pendidikan kimia telah menganalisis bahwa terdapat empat konsep kimia yang sering menjadi kesulitan mahasiswa, yaitu konsep mol, stoikiometri, kesetimbangan kimia dan reaksi redoks. Rendahnya pemahaman mahasiswa terhadap keempat konsep kimia di atas selain karena konsep-konsep kimia tersebut bersifat abstrak, juga disebabkan adanya aspek hitungan [1].

Pada pokok bahasan stoikiometri, kesalahan konsep yang terjadi meliputi perhitungan perbandingan massa atom dalam molekul [2], penentuan mol suatu senyawa dengan menggunakan koefisien reaksi [3], menentukan reaksi pembatas, dan menghubungkan beberapa konsep dalam penyelesaian soal-soal stoikiometri $[4,5]$

Rendahnya pemahaman mahasiswa terhadap konsep-konsep stoikiometri di atas juga terjadi pada mahasiswa Program Studi Pendidikan Matematika FKIP Universitas Mataram setiap tahun pelajaran, sehingga mempengaruhi prestasi belajar pada mata kuliah kimianya. Data hasil belajar mahasiswa angkatan 2007/2008 untuk pokok bahasan stoikiometri adalah sebesar 50,75\% mahasiswa mendapatkan nilai di bawah 65. Masalah ini perlu segera diatasi dengan tindakan nyata, mengingat materi stoikiometri merupakan materi dasar yang harus dikuasai mahasiswa untuk mempelajari materi selanjutnya pada mata kuliah kimia dasar. Tindakan nyata yang dapat digunakan adalah dengan melakukan inovasi dalam pembelajaran, diantaranya dengan menerapkan pembelajaran kooperatif, yaitu model pembelajaran yang memberi kesempatan pada siswa untuk bekerjasama dalam mengatasi berbagai persoalan.

Salah satu model pembelajaran kooperatif adalah berkirim salam dan soal. Teknik belajar mengajar berkirim salam dan soal memberi siswa kesempatan untuk melatih pengetahuan dan ketrampilan mereka. Siswa membuat pertanyaan sendiri, sehingga akan lebih terdorong untuk belajar dan menjawab pertanyaan yang dibuat oleh temanteman sekelasnya [6].

Berdasarkan latar belakang di atas, maka dalam penelitian ini penulis menerapkan pembelajaran kooperatif berkirim salam dan soal pada mahasiswa program studi matematika FKIP Unram guna mengatasi kesalahan konsep mahasiswa dalam mempelajari stoikiometri. 


\section{METODE PENELITIAN}

Penelitian ini merupakan penelitian tindakan kelas dengan subjek penelitian adalah mahasiswa program situsi pendidikan matematika FKIP Universitas Mataram tahun akademik 2008/2009. Langkah-langkah penelitian untuk setiap siklus meliputi perencanaan meliputi pembuatan skenario pembelajaran dengan menggunakan model pembelajaran kooperatif berkirim salam dan soal, pembuatan lembar observasi dan alat evaluasi materi pelajaran. Tahap tindakan meliputi sosialisasi kepada mahasiswa tentang model pembelajaran yang digunakan, pembentukan kelompok mahasiswa dimana masingmasing kelompok berisi 4 orang, penyajian materi dengan metode ceramah dan tanya jawab, dan menerapkan pembelajaran kooperatif berkirim salam dan soal. Tahap observasi adalah mengamati aktivitas mahasiswa yang nampak selama proses pembelajaran oleh pengamat dan dicatat pada lembar observasi. Pada akhir tindakan dilakukan evaluasi hasil belajar dengan cara memberikan tes hasil belajar yang dikerjakan secara individu. Tahap refleksi adalah tahap dimana peneliti mengkaji hasil yang diperoleh dari pemberian tindakan tiap siklus.

Adapun langkah-langkah dalam pembelajaran kooperatif berkirim salam dan soal adalah sebagai berikut:

1. Guru membagi siswa dalam kelompok berempat dan setiap kelompok ditugaskan untuk menuliskan beberapa pertanyaan yang akan dikirim kepada kelompok yang lain. Guru bisa mengawasi dan membantu memilih soal-soal yang cocok.

2. Kemudian, masing-masing kelompok mengirimkan satu orang utusan yang akan menyampaikan salam dan soal dari kelompoknya.

3. Setiap kelompok mengerjakan soal kiriman dari kelompok lain.

4. Setelah selesai, jawaban masing-masing kelompok dicocokkan dengan jawaban kelompok yang membuat soal.

Data yang diperoleh pada penelitian ini meliputi data aktivitas mahasiswa dalam melaksanakan pembelajaran dan kesalahan konsep mahasiswa. Faktor yang diselidiki dan tercantum pada lembar observasi adalah aktivitas mahasiswa dalam mengikuti pembelajaran, interaksi mahasiswa dengan dosen, interaksi sesama mahasiswa, kerjasama antar mahasiswa, aktivitas mahasiswa dalam diskusi, aktivitas mahasiswa dalam melaksanakan pembelajaran, partisipasi mahasiswa dalam menyimpulkan hasil belajar. Aktivitas mahasiswa dianalisis ditentukan berdasarkan kriteria seperti pada Tabel 1.

Tabel 2.1 Kriteria aktivitas mahasiswa [7]

\begin{tabular}{|c|l|l|}
\hline No & \multicolumn{1}{|c|}{ Skor } & \multicolumn{1}{|c|}{ Kategori aktivitas } \\
\hline 1 & $\mathrm{Mh}+1,5 \mathrm{Sdh}$ ke atas & sangat aktif \\
2 & $\mathrm{Mh}+0,5 \mathrm{Sdh} \mathrm{s} / \mathrm{d} \mathrm{Mh}$ & baik/aktif \\
& $+1,5 \mathrm{Sdh}$ & \\
3 & $\mathrm{Mh}-0,5 \mathrm{Sdh} \mathrm{s} / \mathrm{d} \mathrm{Mh}+$ & cukup baik/cukup aktif \\
& $0,5 \mathrm{Sdh}$ & \\
4 & $\mathrm{Mh}-1,5 \mathrm{Sdh} \mathrm{s} / \mathrm{d} \mathrm{Mh}-$ & kurang baik/kurang aktif \\
& $0,5 \mathrm{Sdh}$ & \\
5 & Kurang dari $\mathrm{Mh}-1,5$ & sangat kurang baik/sangat \\
& Sdh & kurang aktif \\
\hline
\end{tabular}

Dimana: $\mathrm{Mh}=(\mathrm{Xth}+\mathrm{Xrh}) / 2$ dan $\mathrm{Sdh}=(\mathrm{Xth}+\mathrm{Xrh}) / 6$

Keterangan:

$\mathrm{Mh}=$ nilai rata-rata harapan

$\mathrm{Sdh}=$ Standar deviasi harapan

$\mathrm{Xth}=$ nilai tertinggi harapan

$\mathrm{Xrh}=$ nilai terendah harapan

Untuk mengetahui banyaknya mahasiswa yang mengalami kesalahan konsep, data penelitian yang diperoleh dianalisis dengan rumus berikut:

$$
\mathrm{KK}=\frac{\mathrm{SS}}{\mathrm{SK}} \times 100 \%
$$

Keterangan:

KK : Kesalahan Konsep

SS : Jumlah skor jawaban yang salah

SK : Jumlah skor jawaban keseluruhan

Dengan kriteria kesalahan konsep sebagai berikut:

Table 2.2 Kriteria kesalahan konsep mahasiswa

\begin{tabular}{|c|c|c|}
\hline No & Skor & Kategori kesalahan konsep \\
\hline 1 & $0 \%<\mathrm{KK} \leq 20 \%$ & $\begin{array}{l}\text { sangat sedikit mahasiswa mengalami } \\
\text { kesalahan konsep }\end{array}$ \\
\hline 2 & $20 \%<\mathrm{KK} \leq 40 \%$ & $\begin{array}{l}\text { sedikit mahasiswa mengalami } \\
\text { kesalahan konsep }\end{array}$ \\
\hline 3 & $40 \%<\mathrm{KK} \leq 60 \%$ & $\begin{array}{l}\text { cukup banyak mahasiswa mengalami } \\
\text { kesalahan konsep }\end{array}$ \\
\hline 4 & $60 \%<\mathrm{KK} \leq 80 \%$ & $\begin{array}{l}\text { banyak mahasiswa mengalami } \\
\text { kesalahan konsep }\end{array}$ \\
\hline 5 & $80 \%<\mathrm{KK} \leq 100 \%$ & $\begin{array}{l}\text { sangat banyak mahasiswa mengalami } \\
\text { kesalahan konsep }\end{array}$ \\
\hline
\end{tabular}

Keberhasilan tindakan dilihat dari menurunnya tingkat kesalahan konsep mahasiswa dimana harapkan sangat sedikit mahasiswa (0\%-20\%) yang mengalami kesalahan konsep dan mahasiswa sangat akatif dalam melaksanakan proses belajar mengajar. Apabila kelas belum mencapai kriteria tersebut maka penelitian tindakan dilanjutkan pada siklus berikutnya. Tindakan yang dipilih pada siklus ini direncanakan berdasarkan hasil refleksi dari tindakan pada siklus sebelumnya.

\section{HASIL DAN PEMBAHASAN \\ 3.1. Hasil Siklus I}

Pada siklus I, sub pokok bahasan yang dibahas mengenai hukum-hukum dasar persenyawaan kimia, massa atom relatif dan massa molekul relatif selama dua kali pertemuan. Jumlah kelompok sebanyak 10 dengan jumlah anggota pada masing-masing kelompok sebanyak 4 orang. Hasil observasi pada pertemuan I siklus I menunjukkan aktivitas mahasiswa pada kategori kurang aktif. Pada tahap dimana masing-masing kelompok ditugaskan untuk mencari soal, hanya beberapa mahasiswa dalam kelompok tersebut yang aktif mencari soal sedangkan sebagian besar anggota kelompok hanya bertindak sebagai penonton. Begitu pula, pada saat salah satu kelompok ditugaskan untuk menyampaikan soal yang telah dikerjakan kepada kelompok lain, antusiasme kelompok masih kurang.

Tahap dimana masing-masing kelompok mencocokkan jawaban dengan kelompok pembuat soal, interaksi antara anggota kelompok masih kurang. 
Mahasiswa yang menyampaikan jawaban dan berperan dalam diskusi antar kelompok hanya satu orang, sedangkan anggota kelompok yang lain lebih banyak berdiam diri. Dengan kata lain partisipasi mahasiswa sebagian besar $(57,5 \%)$ hanya sebagai penonton. Partisipasi mahasiswa dalam menyampaikan hasil diskusi juga sangat kurang.

Pada pertemuan II, sudah terlihat adanya peningkatan interaksi mahasiswa dengan mahasiswa yang lain meskipun aktivitas mahasiswa dalam diskusi dan menyimpulkan hasil diskusi masih kurang. Hasil observasi pada pertemuan II menunjukkan aktivitas mahasiswa pada kategori cukup aktif. Keseluruhan hasil observasi pada siklus I menunjukkan aktivitas mahasiswa pada kategori cukup aktif.

Hasil belajar siswa pada siklus I menunjukkan ratarata kelas 47,9 dengan kesalahan konsep sebesar 52,10\% (Tabel 3). Hasil tersebut menunjukkan cukup banyak mahasiswa yang mengalami kesalahan konsep. Dari hasil analisis jawaban mahasiswa, masih banyak yang belum dapat menerapkan hukum-hukum dasar persenyawaan kimia untuk menyelesaikan soal-soal perhitungan. Sedangkan dalam memahami massa atom relatif dan massa molekul relatif berikut cara menentukan massa atom relatif sudah menunjukkan tingkat pemahaman yang cukup baik jika dibandingkan dengan sub pokok bahasan hukumhukum dasar persenyawaan kimia.

Tabel 3.1 Hasil Evaluasi pada Siklus I

\begin{tabular}{|l|l|}
\hline Rata-rata skor & 47,9 \\
\hline Skor Tertinggi & 90 \\
\hline Skor Terendah & 17 \\
\hline Kesalahan Konsep & $52,10 \%$ \\
\hline
\end{tabular}

Berdasarkan hasil pengamatan pada siklus I ditemukan beberapa kekurangan yaitu (1) interaksi beberapa mahasiswa dengan mahasiswa lain kurang, begitu juga interaksi mahasiswa dengan dosen (2) dosen lebih banyak memberikan motivasi dan arahan kepada mahasiswa yang tidak aktif baik dalam diskusi maupun dalam menyimpulkan sub pokok bahasan yang telah dibahas. Untuk itu, perlu dirancang metode pembelajaran yang efektif guna menyempurnakan model pembelajaran yang telah dilakukan pada siklus I.

\subsection{Hasil Siklus II}

Sub pokok bahasan yang dibahas pada siklus II meliputi konsep mol, rumus kimia dan perhitungan kimia. Model pembelajaran yang digunakan hampir sama dengan model pembelajaran pada siklus I, hanya saja dengan perbaikan-perbaikan sesuai hasil evaluasi dan refleksi pada siklus I.

Hasil observasi pada siklus II menunjukkan partisipasi mahasiswa dalam mengikuti pembelajaran meningkat. Mahasiswa dengan tingkat partisipasi baik, cukup, kurang berturut-turut sebesar $42,4 \% ; 45 \% ; 12,5 \%$. Berbeda dengan siklus I dimana hanya $17,5 \%$ mahasiswa dengan partisipasi baik sedangkan 57,5\% menunjukkan mahasiswa dengan partisipasi kurang. Keseluruhan hasil observasi pada siklus II menunjukkan aktivitas mahasiswa pada kategori baik/aktif.
Meningkatnya partisipasi mahasiswa dalam mengikuti pembelajaran terlihat dari diskusi dimana mahasiswa tidak lagi mengandalkan wakil dari kelompoknya, melainkan semua anggota kelompok ikut berperan dalam diskusi. Kerjasama mahasiswa dengan mahasiswa lain dalam satu kelompok serta interaksi mahasiswa dengan dosen meningkat. Pada saat mengerjakan soal yang disampaikan kelompok lain, terlihat antusiasme mahasiswa yang tinggi dibandingkan pada siklus I. Hampir semua mahasiswa berlomba-lomba ingin mengerjakan soal di depan kelas. Mahasiswa yang pada siklus I terlihat pasif, menjadi lebih aktif pada siklus II. Namun demikian, masih ada beberapa mahasiswa yang kurang antusias dalam mengikuti diskusi atau hanya bertindak sebagai penonton. Dalam menyampaikan hasil diskusi, terlihat partisipasi semua kelompok di dalam memberikan pendapat. Berbeda dengan siklus I yang didominasi oleh beberapa kelompok saja.

Hasil evaluasi terhadap tingkat kemampuan dalam memahami materi kuliah menunjukkan terjadi peningkatan pada rata-rata kelas dan penurunan jumlah mahasiswa yang mengalami kesalahan konsep. Rata-rata kelas pada siklus II adalah sebesar 81,85 dengan kesalahan konsep sebesar 18,15\% (Tabel 4). Hasil tersebut menunjukkan sangat sedikit mahasiswa yang mengalami kesalahan konsep. Dari hasil analisis jawaban menunjukkan beberapa mahasiswa kurang dapat menghubungkan konsep-konsep yang sudah diberikan dalam menyelesaikan perhitungan kimia.

Tabel 3.2. Hasil Evaluasi pada Siklus II

\begin{tabular}{|l|l|}
\hline Rata-rata skor & 81,85 \\
Skor tertinggi & 100 \\
Skor terendah & 23 \\
Kesalahan konsep & $18,15 \%$ \\
\hline
\end{tabular}

\subsection{Pembahasan}

Hasil penelitian pada siklus I menunjukkan tingkat partisipasi mahasiswa yang kurang dengan cukup banyak mahasiswa yang mengalami kesalahan konsep. Berdasarkan hasil tersebut dilakukan perbaikan-perbaikan pada siklus II dengan lebih banyak memberikan motivasi dan arahan kepada mahasiswa yang tidak aktif. Selama ini, mahasiswa hanya terpaku pada materi yang diberikan dosen sehingga pembelajaran bersifat satu arah. Mahasiswa cenderung bersifat lebih pasif dalam proses pembelajaran.

Pembelajaran kooperatif didasarkan pada kerjasama mahasiswa dalam kelompok-kelompok kecil, saling menyumbangkan pikiran dan bertanggung jawab terhadap pencapaian hasil belajar secara individu maupun kelompok [8]. Pembelajaran kooperatif berkirim salam dan soal memberi kesempatan mahasiswa melatih pengetahuan dan ketrampilan. Mahasiswa dituntun untuk membuat pertanyaan sendiri sehingga akan lebih termotivasi untuk menjawab pertanyaan yang dibuat oleh mahasiswa yang lain [6]. Terdapat lima unsur yang harus ada dalam pembelajaran kooperatif yaitu, (1) adanya saling ketergantungan positif dan saling terikat antar sesama anggota kelompok (2) interaksi tatap muka antar siswa (3) pertanggungjawaban individu (4) ketrampilan 
berinteraksi antar individu dan kelompok, dan (5) keefektifan proses kelompok [6]. Dengan demikian, proses pembelajaran menjadi lebih menarik dan tidak membosankan mahasiswa.

Pada siklus II, dosen lebih banyak memberikan motivasi dan arahan kepada mahasiswa yang tidak aktif dalam diskusi kelompok sehingga tidak hanya mengandalkan wakil dari kelompoknya. Ada dua kelompok yang terlihat hanya mengandalkan wakil dari kelompoknya yaitu kelompok 2 dan 5 sehingga dosen lebih banyak memberikan motivasi dan arahan pada anggota kelompok yang tidak aktif dari kedua kelompok tersebut. Dengan demikian, semua anggota kelompok akan merasa bertanggung jawab terhadap hasil belajar kelompoknya sehingga prestasi belajar setiap mahasiswa dapat dimaksimalkan. Mahasiswa dengan tingkat kemampuan yang tinggi dalam kelompok, dapat menjadi tutor bagi mahasiswa dengan tingkat kemampuan yang rendah sehingga saling menguntungkan satu dengan yang lain [9]. Peranan dosen dalam pembelajaran kooperatif adalah mendesain sarana sumber bacaan, memfasilitasi kerja kelompok dan diskusi antar kelompok dalam kelas serta mengobservasi dan mengevaluasi kegiatan mahasiswa [10].

Berdasarkan hasil observasi dan evaluasi pada siklus II, menunjukkan peningkatan aktivitas mahasiswa dan berkurangnya mahasiswa yang mengalami kesalahan konsep. Hal ini dapat dipahami karena motivasi mahasiswa dalam mengikuti proses pembelajaran dapat mempengaruhi prestasi belajar mahasiswa. Mahasiswa yang awalnya tidak aktif, menjadi bergairah untuk dapat menyelesaikan soal-soal yang telah mereka buat. Dengan demikian, pembelajaran kooperatif berkirim salam dan soal dapat meningkatkan kualitas pembelajaran mahasiswa program studi matematika FKIP Unram tahun akademik 2008/2009 untuk pokok bahasan stoikiometri.

\section{KESIMPULAN}

Pembelajaran kooperatif berkirim salam dan soal mampu mengatasi kesalahan konsep mahasiswa program studi matematika FKIP Unram tahun akademik 2008/2009 pada pokok bahasan stoikiometri. Oleh karena itu, disarankan pendekatan kooperatif perlu diterapkan pada pokok bahasan yang lain dengan model yang berbeda sehingga memperkaya wawasan dalam pembelajaran.

\section{DAFTAR PUSTAKA}

[1] Fach M, de Boer T, Parchmann I. 2007. Results of an interview study as basis for the development of stepped supporting tools for stoichiometric problems. Chemistry Education Research and Practice 8(1): 13-31.

[2] Schmidt HJ. 1990. Secondary school students strategies in stoichiometry. International Journal of Science Education 12: 457-471.

[3] BouJaoude S, Barakat H. 2000. Secondary school students "diffuculties with stoichiometry". School Science Review 81(296):91-98.

[4] Huddle PA, Pillay AE. 1996. An in-depth study of misconceptions in stoichiometry and chemical equilibrium at a South African University. Journal of Research in Science Teaching 33: 65-77.

[5] Furio C, Azcona R, Guisasola J. 2002. The learning ang teching of the concepts amount of substance and mole: a review of the literature. Chemistry Education Research and Practice 3: 277-292.

[6] Lie A. 2003. Cooperative Learning, Mempraktekkan Cooperative Learning di Ruang kelas. Jakarta: Gramedia Widya Sarana.

[7] Anonim. 2004. Pedoman Penilaian Afektif. Departemen Pendidikan Nasional Direktorat Jenderal Pendidikan Dasar dan Menengah. Direktorat Pendidikan Lanjutan Pertama. Jakarta

[8] Slavin R.1991. Synthesis of research on cooperative learning. Educational Leadership 48(5): 81-82.

[9] Ibrahim M. 2000. Pembelajaran Kooperatif. Surabaya: Universitas Negeri Surabaya University Press.

[10] Djamarah SB, Zain A. 1996. Strategi Belajar Mengajar. Jakarta: Rineka Cipta. 